\title{
The Effectiveness of Celebrity Endorsement in Instagram for Local Food Brand on Indonesia's Customers Attitude Towards Brand and Purchase Intention
}

\author{
$1^{\text {st }}$ Farida Komalasari \\ School of Business \\ President University \\ Bekasi, Indonesia \\ farida_k@president.ac.id
}

\author{
$2^{\text {nd }}$ Kristie Liliani \\ School of Business \\ President University \\ Bekasi, Indonesia
}

\begin{abstract}
The purpose of this research is to examine the factors that affect purchase intention toward local food brand in Indonesia mediated by attitude towards brand. Meanwhile, the independent variable in this research is celebrity endorsement with sub-dimensions of expertise, trustworthiness, attractiveness, likability, personality, and familiarity also added with similarity and celebrity match-up congruence with the brand/product. A quantitative research is conducted by distributing an online questionnaire which consists of 50 statements. There were 217 respondents, chosen by using snowball sampling. A validity and reliability test were conducted by using statistical software, as well as model-fit, hypothesis testing and R-Square were analyzed by Structural Equation Model (SEM) analysis. The result shows that celebrity attractiveness, celebrity personality and celebrity match-up congruence with the brand have a significant effect on attitude towards brand. It is also found that celebrity similarity and attitude towards brand have a significant effect on purchase intention of local food brand in Indonesia. Meanwhile celebrity expertise, celebrity trustworthiness and celebrity familiarity do not have a significant influence on attitude towards brand and purchase intention. Furthermore, it is found that celebrity attractiveness, celebrity personality and celebrity match-up congruence don't have a significant effect on purchase intention. In addition, celebrity similarity is found to have no significant effect on attitude towards brand.
\end{abstract}

Keywords-Celebrity Endorsement, Instagram, Local Food Brand, Customer

\section{INTRODUCTION}

The development of Indonesia's export economy, especially for the culinary sub-sector from 2010 to 2016 experienced an improvement, both in value and net weight. Culinary becomes the biggest contributor to GDP of creative economy. ${ }^{[1]}{ }^{[2]}$ The contribution of the culinary sub-sector to the creative economy GDP in 2016 reached $41.40 \%$ with an income of IDR 382 trillion from the total of IDR 922 trillion in 2016. This number is the highest compared to the other 16 sub-sectors in BEKRAF RI. ${ }^{[3]}$

On the other hand, compared to Thailand, Malaysia and Vietnam, Indonesia local food and beverage products are considered not be able to win the market. This is because their food and beverage industry relatively has cheaper prices and offer a well packaged product that are attractive and unique. ${ }^{[4]}$

According to Tellström, Gustafsson and Mossberg, food is an integral part of the culture of communication and can be used for both economic and political purposes. In addition, ethnic habits and community beliefs are also related to preferences for certain foods in different communities.[5] It can be affected by the using of Instagram as a social media application. that is known worldwide. Instagram is an application where people can share pictures and videos, its supportive appearance and lots of active users are used as business platform.[6] Instagram becomes the seventh largest social media in the world and the fourth largest in Indonesia, in term of user.[7] In addition, Facebook and Instagram are the most used social media by traders in Indonesia to promote their business.[8] It's easy to apply the benefit of social media as a platform to promote a business, since the number of users of social media is now increasingly widespread.[9] .

There is a phenomenon in the world of social media, especially in Instagram, namely selebgram. Selebgrams mean people with high popularity (microcelebrity) on Instagram.[6] Of course this becomes interesting to see the phenomenon of the emergence of celebrities, and endorse. The sellers are eyeing these celebrities to promote their goods with the hope that the audience will be more interested in seeing items that are used by the celebrities.[10] 
There are so many celebrity endorsement categories ranging from beauty, motivational to culinary. One category that attracts followers is culinary. Culinary is indeed a very interesting topic because the presentation is unique and funny, wrapped with the creativity of the content created and presented by the celebrity. In addition, these culinary celebrities review the food and restaurants they visited.[11] Characteristics that are considered in affecting customer's purchase intention through customer's attitude towards brand are their trustworthiness, expertise and attractiveness in doing the endorsement.[12]

According to those phenomenons, this research is meant to answer questions whether celebrity endorsment affects the customer's attitude towards brand and purchase intention on local food brand in Indonesia. Therefore, the research objectives are to figure out the effect of celebrity endorsement on customer's attitude towards brand and on customer's purchase intention; and to figure out the effect of customer's attitude towards brand on customer's purchase intention of local food brand in Indonesia.

So, this research result are accomplished to business players on local food brand to develop their business through social media by using celebrity endorsement as a marketing medium. This research result also will help the celebrity as local food product endorser to perform better.

\section{LITERATURE REVIEW}

\section{A. Purchase Intention}

Purchase intention is a potential or a tendency to buy certain products. ${ }^{[13]}$ Purchase intention also can be defined as a promise made by someone against him/herself to buy a product when visiting a market. ${ }^{[14]}$ Customer willingness is one of the element that influences customers in considering to buy a product, make a decision to buy products in the future and repurchase intention of customers. ${ }^{[15]}$ The one of the factor affecting purchase intention is attitude towards brand. ${ }^{[16]}$ In this research, purchase intention is measured by 5 statements. ${ }^{[13]}$

\section{B. Attitude towards Brand}

Attitude towards brand is outlined as the overall evaluation made by consumer towards a certain brand. This is an assessment of the response given by consumer. It is also give an advantages and disadvantages towards a brand's trust. ${ }^{[17]}$ Other than that, another definition is a focus on the tendency for adverse and profitable impacts on a product that arises when consumers watch the brand's ad. ${ }^{[13]}$ In addition, it is also a reaction that is given emotionally by the customer. Furthermore, it also has something to do with the customer's feelings about the purchase intention of a brand. On the contrary, it is found that celebrity endorsement has a good effect in affecting consumer attitude towards brand. ${ }^{[18]}$ In this research, attitude towards brand is measured by 5 statements. ${ }^{[13]}$

\section{Celebrity Endorsment}

Promotional tools that are currently being used by lots of business players is celebrity endorsement. ${ }^{[15]}$ In this modern era, celebrity endorsement become an important feature in doing the marketing and it keeps growing as time goes by. ${ }^{[19]}$ Celebrity endorsement is a way of communicating used by celebrities as a medium to express the intention to promote products through their fame. The two general models in analyzing the celebrity endorsement are the source of credibility model and the source of attractiveness model. ${ }^{[13]}$ The source of credibility model consists of expertise and trustworthiness. Meanwhile, the source of attractiveness consists of celebrity's attractiveness, liking, familiarity, similarity and celebrity's match-up congruence with the brand. ${ }^{[13][16]}$ So, totally there is 8 variables of celebrity endorsement and measured by 40 modified statements from three sources. ${ }^{[8][13][16]}$ Those 8 variables are explained below.

Celebrity expertise is defined as the knowledge and experience of an endorser's in a particular field occupied.[20] Expertise shown by the celebrity makes customers or viewers conclude that the celebrity review the product based on the experience when they tried/consumed the product. It will lead the customers to think that it is worth to try and end up buying the product being endorsed to fill their curiosity and satisfy their wants/needs.[19]

Celebrity trustworthiness is also clarified as the level of trust in the communicator's expectation to impart the statements he/she considers being the most legitimate.[21] Trustworthiness is identified with respectability, honesty and dependability of an endorser as saw by the intended target audience.[22]

Celebrity attractiveness is more likely related to physical appearance and attributes such as elegance, handsome/beautiful and manner.[21] The attractiveness can create a good and positive point of view towards purchase intention. It's also supported by Ohanian that attractiveness has a significant relation with attitude towards brand if the product is being endorsed by a well-known figure.[23] Other than physical attractiveness, there are other several concepts/sources entailed by attractiveness such as personality properties, skills of endorsers, athletic performances, way of living, and intellectual skills [16]

Celebrity likeability is the attachment and affection of the source created by the behavior, attitude and physical appearance. If customers like the celebrity, they will like celebrity-related brands. Furthermore, when people find one celebrity interesting, they will like the celebrity and believe that the brand being used by the celebrity is a good one and indirectly like the brand too. This is the reason why celebrity are used in doing marketing strategy such advertisement and commercial.[13]

Celebrity personality is most often described in terms of a measurable trait that a person shows. The dominant approach of personality is linked with the description of attitude and behavior.[24] Personality is categorized into 4 types, those are extraversion, agreeableness, conscientiousness and openness to experience. Based on those types of personality, there are some breakdown inside it such as kind, friendly, polite and cheerful.[25]

Celebrity familiarity, as mentioned by Erdogan, implies the sentiment of closeness by methods for feelings and contact with a celebrity. In other hand, Zajonc stated that celebrity familiarity will have a better impact and result when the customer finds that he/she is similar to the celebrity in terms of lifestyle and routine they have. It can be categorized as the mere exposure effect.[13]

Celebrity similarity is described as an equality that is bound between the recipient and the source of the message. Hence, a customer may equalize him/herself with the endorser and think that they might have the same thing in common. People are more easily being influenced when they think and find their selves share the same similarity 
with the endorser. A better association will be bound when both customer and the celebrity share a major factors such as lifestyle and interest.[13]

Previous study conducted by Cooper and Forkan in Ha \& Lam [13 found that celebrity match-up congruence with the brand plays a significant role. Furthermore, compared with the advertisement promoted by less relevant and less famous person, the confidence will be much more higher if a product advertised or endorsed by a celebrity that match more or have a high relevant with the product.[13]

\section{Relationship among Variables}

At least there is four studies about the relationship between celebrity endorsement and attitude towards brand. The first study showed that celebrity endorsement creates a better attitude towards advertising also purchase intention instead of non-celebrity endorsement. [18] The second, third, and fourth studies showed the same result that celebrity endorsement positively affected attitude towards brand.[13] [26] [27]

A previous study showed that attitude towards brand is the most influencing variable that can be used to make a better impression of a product. One of the method that can be utilized is celebrity endorsement.[15] The other research indicated that purchase intention is strongly and positively affected by customer's attitude towards brand.[13] [16]

A previous study found that purchase intention is positively affected by celebrity endorsement with 3 important sub dimension on it which are expertise, trustworthiness and attractiveness.[22] Another study showed that celebrity endorsement with credibility and attractiveness dimensions are positively affect purchase intention. ${ }^{[26]}$

\section{E. Research Gap}

The difference of this research compared to the previous research are in the dimension number of the celebrity endorsement variable, the analysis method used, and the research's object. From the number of variable's dimension, this research uses 8 dimensions of celebrity endorsement while others use 3-5 dimensions. ${ }^{[15]}[16][22]$ From the analysis method, this research uses Structural Equation Model (SEM), while the others use SmartPLS. ${ }^{[22]}$ From the research object, this is the first research in Indonesia about local food brand and celebrity endorsement. It can be found there was a research about the effect of celebirty endorsement on purchase intention mediated by attitude toward brand, but in fashion local brand. ${ }^{[27]}$

\section{RESEARCH METHOD}

The research framework is shown on Figure 1. There is 8 dimensions of celebrity endorsement as independent variables, attitude towards brand as mediating variable and purchase intention as dependent variable. Be accordance with the theoretical framework, hypothesis constructed for this research is stated below:

- Celebrity expertise influences attitude towards brand (H1a) and purchase intention (H1b)

- Celebrity trustworthiness influences attitude towards brand $(\mathrm{H} 2 \mathrm{a})$ and purchase intention $(\mathrm{H} 2 \mathrm{~b})$

- Celebrity attractiveness influences attitude towards brand (H3a) and purchase intention (H3b)

- Celebrity likability influences attitude towards brand (H4a) and purchase intention (H4b)

- Celebrity personality influences attitude towards brand (H5a) and purchase intention (H5b)

- Celebrity familiarity influences attitude towards brand (H6a) and purchase intention (H6b)

- Celebrity similarity influences attitude towards brand (H7a) and purchase intention (H7b)

- Celebrity match-up congruence with the brand/product influences attitude towards brand (H8a) and purchase intention (H8b)

- Attitude towards brand influences purchase intention.

This research is quantitative research using primary data, collected using questionnaire. The questionnaire consists of three parts. The first is about screening questions to get the right samples. The second is about respondents' profile, includes gender, age, employment status and monthly expenditure. The third is about the 3 variables' group, consists of 50 statements; 40 statements for celebrity endorsement with 8 dimensions, 5 statements for attitude towards brand and last 5 statements for purchase intention. Those are measured with 1-7 point likert scale with 1means strongly disagree and 7 means strongly agree. 


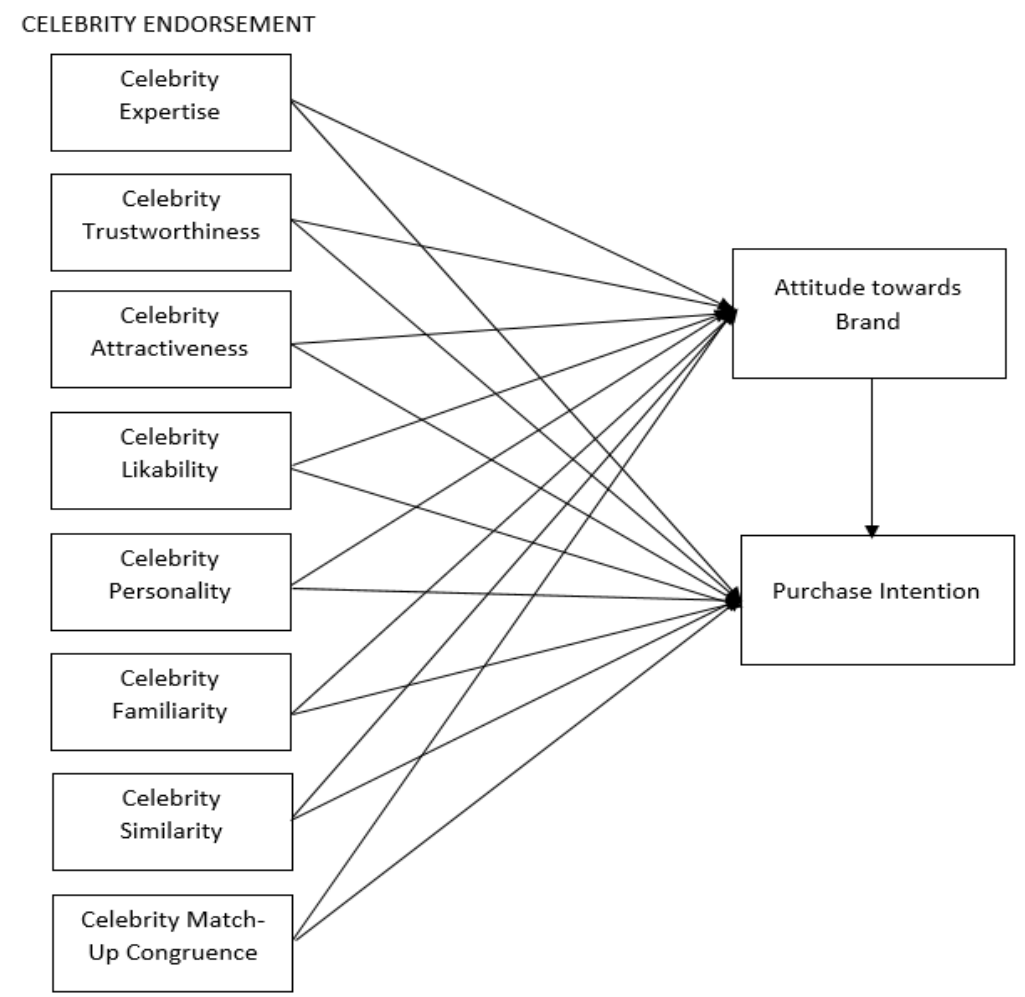

Fig. 1. Theoretical Framework

Population of this research is people domiciled in Indonesia who have an Instagram account and ever made a purchase towards Indonesia's local food brand. The number of sample is 217, chosen by using snowball sampling.

Before analyzing the data, validity and reliability test are done using a Kaiser-Meyer-Olkin (KMO) \& Bartlett's test, and a Cronbach's Alpha test respectively.

For valid and reliable data, descriptive and inferential analysis are applied. Descriptive analysis is done with the aim to gather the respondent's profile and characteristic of each variable. It's also can be used to adjust the data/sample collected to be easier to be understood. ${ }^{[28]}$ Descriptive analysis provides the information descriptively and statistic result for mean and standard deviation. ${ }^{[29]}$ Since there is three groups of variable (independent variable, mediating variable, and dependent variable) and the number of sample exceeds than 200, a SEM is used for inferential analysis. It covers a goodness of fit testing, hypothesis testing, and determinant analysis. ${ }^{[30]}$

\section{RESULT AND DISCUSSION}

The validity test result shows that 5 statements of celebrity likability and one statements of celebrity familiarity are not valid. These 6 statements are not included in the next step, that is reliability test. The reliability test result shows that the all data are reliable.

The majority respondents are female $(65 \%)$, in the range of age between 15-24 years old (97.9\%), and most of them are college students $(70 \%)$ with a monthly expenditure for food in the range of IDR1.000.000$3.000 .000(66,9 \%)$

Generally, the respondents' answer for all statements are in the range of 4.3041-5.7788, with the standard deviation in the range of 1.09168-1.70920. Those mean that most of respondents agree with the statements stated for all variables. The respondents agree that the celebrity as local food brand endorser has a good expertise, trustable, attractive, has a good personality, familiar, similar with them, and suitable with the brand. Related with the attitude towards brand variable, the respondents show a good evaluation toward a certain local food brand. The last variable is purchase intention. It can be seen that respondents show a potential or a tendency to buy certain local food products.

The inferential analysis result is divided into three parts, goodness of fit testing, hypothesis testing, and determinant analysis. Figure 2 shows the model fit testing diagram and Table 1 shows statistical result of the goodness of fit testing. This research uses four criteria to categorize the model as fit. Those are Incremental Fit Index (IFI; >=0.9), Tucker Lewis Index (TLI; >=0.9), Comparative Fix Index (CFI; >=0.9), and Root Mean Square Error of Approximation (RMSEA; 0.05-0.08). ${ }^{[30]}$ The statistical value of those four criteria are $0.911,0.901$, 0.910 , and 0.066 respectively. So, it can be concluded that the model is a good fit. 


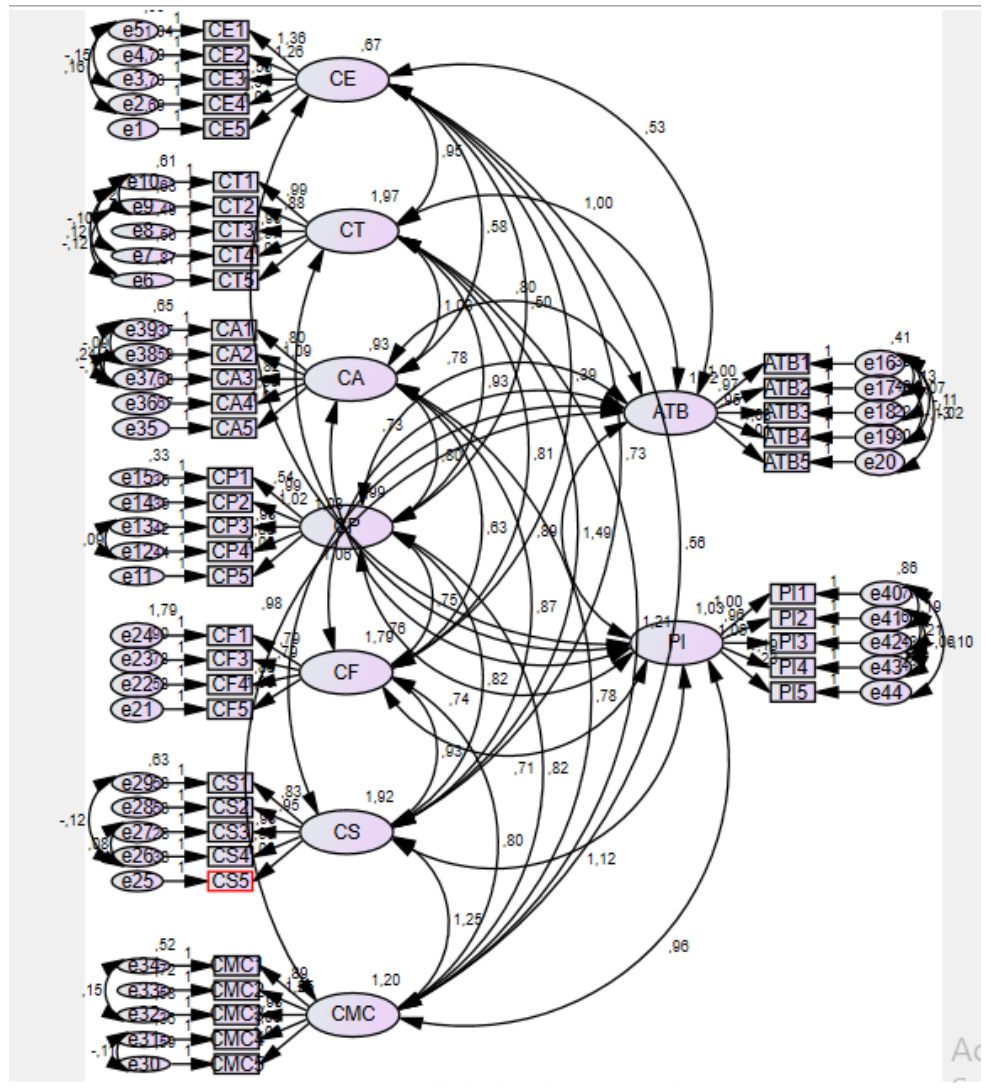

Source: Statistical Software Result

Fig. 2. The Model Fit Path Diagram

The second part is hypothesis testing. Table I shows the hypothesis regression weight. A hypothesis will be accepted if the Critical Ratio-value (CR) is greater than 1,96 and the P-value is below than 0.05 . It can be concluded that
5 hypotheses are accepted and 10 hypotheses are rejected. The accepted hypotheses are H3a, H5a, H7b, H8a, and H9. The rejected hypotheses are $\mathrm{H} 1 \mathrm{a}, \mathrm{H} 1 \mathrm{~b}, \mathrm{H} 2 \mathrm{a}, \mathrm{H} 2 \mathrm{~b}, \mathrm{H} 3 \mathrm{~b}, \mathrm{H} 5 \mathrm{~b}$, H6a, H6b, H7a, and H8b.

TABLE 1. GOODNESS OF FIT INDEX

\begin{tabular}{|c|c|c|c|c|c|c|c|}
\hline \multicolumn{8}{|c|}{ Baseline Comparisons } \\
\hline Model & $\begin{array}{r}\text { NFI } \\
\text { Delta1 }\end{array}$ & $\begin{array}{l}\text { RFI } \\
\text { rho1 }\end{array}$ & & & & & CFI \\
\hline Default model & ,834 &, 813 & & 11 & & & ,910 \\
\hline Saturated model & 1,000 & & & 00 & & & 1,000 \\
\hline Independence model & ,000 &, 000 & & 00 & & & ,000 \\
\hline \multicolumn{8}{|c|}{ RMSEA } \\
\hline Model & RMSEA & \multicolumn{2}{|c|}{ LO 90} & \multicolumn{2}{|c|}{ HI 90} & \multicolumn{2}{|c|}{ PCLOSE } \\
\hline Default model & ,066 & \multicolumn{2}{|c|}{,062 } & \multicolumn{2}{|c|}{,071 } & & 000 \\
\hline Independence model & 209 & \multicolumn{2}{|c|}{,206 } & \multicolumn{2}{|c|}{213} & & ,000 \\
\hline
\end{tabular}

Source: Statistical Software Result

Table 2. Hypothesis Regression Weight

\begin{tabular}{|c|c|c|r|r|r|r|c|}
\hline & & & Estimate & \multicolumn{1}{c|}{ S.E. } & C.R. & P & Label \\
\hline ATB & $<---$ & CE &, 042 &, 058 &, 731 &, 465 & par_36 \\
\hline ATB & $<---$ & CT &,- 062 &, 054 & $-1,154$ &, 249 & par_37 \\
\hline ATB & $<---$ & CA &, 306 &, 088 & 3,481 & $* * *$ & par_38 \\
\hline ATB & $<---$ & CP &, 171 &, 072 & 2,365 &, 018 & par_39 \\
\hline ATB & $<---$ & CF &, 066 &, 050 & 1,329 &, 184 & par_40 \\
\hline ATB & $<---$ & CS &, 107 &, 062 & 1,718 &, 086 & par_41 \\
\hline ATB & $<---$ & CMC &, 527 &, 080 & 6,567 & $* * *$ & par_42 \\
\hline PI & $<---$ & CE &, 060 &, 066 &, 907 &, 364 & par_43 \\
\hline PI & $<---$ & CT &, 030 &, 063 &, 476 &, 634 & par_44 \\
\hline PI & $<---$ & CA &, 157 &, 108 & 1,453 &, 146 & par_45 \\
\hline PI & $<---$ & CP &, 107 &, 084 & 1,279 &, 201 & par_46 \\
\hline
\end{tabular}




\begin{tabular}{|r|r|r|r|r|r|r|r|}
\hline & & & Estimate & S.E. & C.R. & P & Label \\
\hline PI & $<---$ & CF &, 009 &, 057 &, 155 &, 877 & par_47 \\
\hline PI & $<---$ & CS &, 323 &, 074 & 4,373 & $* * *$ & par_48 \\
\hline PI & $<---$ & CMC &, 210 &, 117 & 1,792 &, 073 & par_49 \\
\hline PI & $<---$ & ATB &, 366 &, 122 & 3,011 &, 003 & par_50 \\
\hline \multicolumn{7}{|c|}{ Source: Statistical Software Result }
\end{tabular}

The third part is determinant analysis using the RSquare, that can be seen on Table III. It can be said that $64.9 \%$ of the variance in attitude towards brand is determined by celebrity attractiveness, celebrity personality, and celebrity match-up congruence with the brand. Meanwhile, $62.7 \%$ of the variance in purchase intention is determined by celebrity similarity and attitude towards brand.

TABLE III. R-SQUARE
\begin{tabular}{|c|r|}
\hline & Estimate \\
\hline ATB &, 649 \\
\hline PI &, 627 \\
\hline
\end{tabular}
rirce: Statistical Software Result

The inferential analysis result shown that celebrity expertise does not positively influence attitude towards brand and purchase intention for local food brand. The same result also happened in Indonesia's local fashion brand.[27] Furthermore, another study also supported that celebrity expertise has no effect on purchase intention.[31] In the other side, some research found that celebrity expertise is positively influence attitude towards brand.[13] [32]. This research result indicates that consumers don't really focus on the field that the celebrity expert on. In Indonesia, a celebrity that is focusing in beauty and fashion also sometimes doing the food endorsement and attract consumer attention.

The next result is celebrity trustworthiness doesn't influence both an attitude towards brand and purchase intention. This result is supported by lots of previous study that have been done before. This result is in-line with the study in local fashion brand in Indonesia,[27] but not with a study in Vietnam.[13]. Result of this study can be clarified as the consumer might think that the celebrity is being paid only for endorsing the local food without caring to the taste of the food itself.

About celebrity attractiveness, the result shows that this variable influences attitude towards brand, but does not influence purchase intention of local food brand in Indonesia. This result is different with Pham \& Nguyen study which indicates that celebrity attractiveness influences attitude towards brand and purchase intention.[32] It can be explained as the appearance shown by the celebrity will increase the attention and attitude towards brand. The more attractive the celebrity will increase the image of the food product being endorsed. Consumers tend to see and believe that if the endorser is attractive, so does the product. However, another result found is celebrity attractiveness doesn't influence purchase intention. As have been mentioned above, attractiveness will give more impact on the attitude towards local food brand. The food product itself will become more wellknown instead of increasing the purchase intention.

Celebrity personality does influence attitude towards brand but does not influence purchase intention of local food brand. This can be explained as the personality shown by the celebrity when endorsing the food can lead consumer to think that the brand is a good one. It is only affecting the point of view of customer to the brand not to their purchase intention. This result it supported by the previous study done by Priyankara, et al.[16]

The fifth variable is celebrity familiarity. This variable doesn't have significant impact on both attitude towards brand and purchase intention. Ha \& Lam stated that celebrity familiarity does help consumer to memorize and remember the endorsement or the advertisement, but has no impact on the attitude towards brand.[13] The same result also happened in local fashion brand.[16] [27] So, even the customers know the celebrities well, it will not give impact on the customer's attitude towards brand and purchase intention. The customers may focus on the food taste and appearance.

The sixth variable is celebrity similarity It does not influence attitude towards brand but influences purchase intention. This result is supported by $\mathrm{Ha} \& \mathrm{Lam}$ and Silalahi \& Komalasari.[13] [27]. In other hand, Pham \& Nguyen have another opinion and stated that celebrity similarity does influence attitude towards brand.[32] Similarity gives an effect for the celebrity in way that the celebrity will received more attention and tend to be remembered more easily. It is also found that celebrity similarity has a significant influence towards purchase intention. The thought of having the similarity (taste) in food with the celebrity will create a believe that the product being endorseed will meet their taste and expectation. Therefore, it will increase the purchase intention.

Another finding is celebrity match-up congruence with the brand influences attitude towards brand. It is supported by Silalahi \& Komalasari, Pham \& Nguyen, and Emma \& Matilde. [27] [32] [33] It's stated that when the match-up between celebrity and product is high, it will create a better relation and result. Customer tend to believe that if the taste of the food meet and match with the celebrity's taste, they will give an honest review about the food. Conversely, if the product being endorsed does not have a match with the celebrity, the customer thinks that the celebrity is only paid to endorse the product. This will lead consumer to have a good attitude towards the brand of the food. Futhermore, celebrity match-up congruence is found to have no influence on purchase intention. It's supported by 
Silalahi \& Komalasari and Emma \& Matilde. [27] [33] When the product is being endorsed in an appropiate way by the celebrity, it will increase the popularity of the celebrity more than the product and purchase intention itself.

Lastly, it is found that attitude towards brand influences purchase intention of local food brand. It's supported by Nugraha et.al., Kumar \& Kudeshia, and Silalahi \& Komalasari.[15] [17] [27] It has been proved by lots of previous study that attitude towards brand is trusted as the mediating variable among celebrity endorsement's variable and purchase intention. The more positive impression given by the customer towards the product brand, it will increase the purchase intention.

About the determinant analysis, as been mentioned before, the attitude towards brand's variance is determined by celebrity attractiveness, celebrity personality, and celebrity match-up congruence with the brand with value of $64.9 \%$. The rest can be determined by advertisement. ${ }^{[34]}$ Meanwhile, the purchase intention's variance is determined by celebrity similarity and attitude towards brand with value of $62.7 \%$. The rest can be determined by social ewom. ${ }^{[17]}$

\section{CONCLUSION}

In this digital era, using celebrity endorment to develop the local food brand business is needed. The important dimension of celebrity endorsment that give impact on attitude towards brand and purchase intention are celebrity attractiveness, celebrity personality, celebrity similarity, and celebrity match-up congruence with the brand.

It is recommended for local food brand business players to pay more attention to the celebrity who is going to endorse the product. The celebrity should be attractive, has a good personality, match-up with the brand, and has similarity with targeted customers.

It is very important for the celebrity endorser to pay more attention on those four dimensions above. Just having expertise, trustable and familiarity (popularity) is not enough. The celebrity must have a strategy to be more attractive with a good personality, knowing well about the brand endorsed and the targeted customers' characteristic.

This research focused on local food brand. The other research can be done on other businesses. In term of population, this research's population is Indonesian Instagram user. So, it can be remommended to do a further research for others that are not Indonesian. This research used celebrity endorsment as independent variable. Since nowadays the growth of food blogger in Instagram is increasing, researching the influence of food blogger on attitude toward brand and purchase intention is interesting.

\section{ACKNOWLEDGMENT}

Thank you for the Head of Business Administration and the Dean of School of Business of President University who give us the opportunity to complete this research.

\section{REFERENCES}

[1] A. Dwitjahyono et al., Ekspor Ekonomi Kreatif Tahun 201-2016. Badan Pusat Statistik, 2017. Available: https://www.bps.go.id/publication/download.html?nrbvfeve=Nz RiNWMxNjUwMjUxMzJlOThhMzZjOGYw\&xzmn=aHR0cHM 6Ly93d3cuYnBzLmdvLmlkL3B1YmxpY2F0aW9uLzIwMTgv
MDQvMDkvNzRiNWMxNjUwMjUxMzJ1OThhMzZjOGYwL2 Vrc3Bvci1la29ub21pLWtyZWF0aWYtMjAxMC0yMDE2Lmh0 bWw\%3D\&twoadfnoarfea

[2] Katadata, "Makanan dan Minuman Memimpin Pertumbuhan Industri Manufaktur," katadata.co.id, 2018. [Online]. Available: https://databoks.katadata.co.id/datapublish/2018/02/08/makanandan-minuman-memimpin-pertumbuhan-industri-manufaktur.

[3] S. Agmasari, "Industri Kuliner, Penopang Tertinggi Perekonomian Kreatif di Indonesia," Kompas.com, 2018. [Online]. Available: https://travel.kompas.com/read/2018/02/06/185000027/industrikuliner-penopang-tertinggi-perekonomian-kreatif-di-indonesia

[4] AntaraNews, "Produk makanan Indonesia dinilai masih kalah dengan Thailand," antaranews.com, 2017. [Online]. Available: https://www.antaranews.com/berita/632363/produk-makananindonesia-dinilai-masih-kalah-dengan-thailand.

[5] J. Syahrivar and Chairy, "Bika Ambon of Indonesia : history , culture , and its contribution to tourism sector," vol. 6, pp. 2-7, 2019.

[6] M. B. Aprilianto, "10 Media sosial teraktif di Indonesia, Mana yang sering kamu pakai ?," Brilio.net, 2018. [Online]. Available: https://www.brilio.net/wow/10-media-sosial-teraktif-diindonesia-mana-yang-sering-kamu-pakai-180214v.html\#.

[7] S. Kemp, "Global Digital Analysis; Special Reports," 2019. [Online]. Available: www.wearesocial.com

[8] H. Widowati, "Pedagang Indonesia Paling Banyak Manfaatkan Instagram dan Facebook," katadata.co.id, 2018. [Online]. Available: https://katadata.co.id/berita/2018/09/24/pedagangindonesia-paling-banyak-manfaatkan-instagram-dan-facebook.

[9] M. Hidayah, "Peluang Bisnis dengan Media Sosial," Kompasiana, 2018. [Online]. Available: https://www.kompasiana.com/hidayah06/5b1fcf33ab12ae11e565 0272/peluang-bisnis-dengan-media-sosial. [Accessed: 23-Jun2019].

[10] A. F. Galuh, "Fenomena Selebgram di Indonesia," Kompasiana, 2017. [Online]. Available: https://www.kompasiana.com/angelicagaluh/59cdec8aff24054d1 676df83/fenomena-selebgram-di-indonesia. [Accessed: 23-Jun2019].

[11] N. Fadhila, "5 Selebgram Kuliner yang Harus Kamu Follow !," yooreka.id, 2019. [Online]. Available: https://yooreka.id/take-abreak/5-selebgram-kuliner-yang-harus-kamu-follow/.

[12] A. Spry, R. Pappu, and B. Cornwell, "Celebrity endorsement, brand credibility and brand equity," Eur. J. Mark., vol. 45, no. 6, pp. 882-909, 2011

[13] N. M. Ha and N. H. Lam, "The Effects of Celebrity Endorsement on Customer's Attitude toward Brand and Purchase Intention," Int. J. Econ. Financ., vol. 9, no. 1, p. 64, 2016.

[14] M. I. Tariq, M. R. Nawaz, M. M. Nawaz, and H. A. Butt, "Customer Perceptions about Branding and Purchase Intention: A Study of FMCG in an Emerging Market," J. Basic Appl. Sci. Res., vol. 9572, no. 2, pp. 127-143, 2013.

[15] R. Nugraha, K. A. Kusumawardani, and V. Octavianie, "The Influence of Celebrity Endorsement in Instagram towards Customer Behavior and Purchase Intention," FIRM J. Manag. Stud., vol. 3, no. 2, pp. 1-24, 2018.

[16] R. Priyankara, S. Weerasiri, R. Dissanayaka, and M. Jinadasa, "Celebrity Endorsement and Consumer Buying Intention With Relation to the Television Advertisement for Perfumes," Manag. Stud., vol. 5, no. 2, pp. 128-148, 2017.

[17] A. Kumar and C. Kudeshia, "Social eWOM: Does it Affect the Brand Attitude and Purchase Intention of Brands?," Manag. Res. Rev., vol. 36, no. 7, pp. 700-719, 2017.

[18] D. M. R. Dissanayake and N. Ismail, "Relationship Between Celebrity Endrsement and Brand Attitude: With Reference to Financial Services Sector Brands in Sri Lanka 1 . Overview of The Sri Lankan Financial Services Sector," vol. 1, pp. 472-487, 2014

[19] T. Thomas and J. Johnson, "The Impact of Celebrity Expertise on Advertising Effectiveness: The Mediating Role of Celebrity Brand Fit," Vision, vol. 21, no. 4, pp. 367-374, 2017.

[20] T. Langner and M. Eisend, "Effects of Celebrity Endorsers' Attractiveness and Expertise on Brand Recall of Transformational and Informational Products," Adv. Advert. Res. (Vol. 2), vol. 2, pp. 451-460, 2011.

[21] I. O. Okyere and E. S. Asamoah, "Celebrity Endorser Selection 
Strategies as Effective Marketing Communications Tool in the Automobile Industry - A Review Paper on Related Literature," Int. J. Bus. Mark. Manag., vol. 3, no. 1, pp. 1-15, 2015

[22] R. Widarto, "The Influence of Celebrity Endorsements on Purchase Intention ( A Study on VIVO V7 )," vol. 20, no. 8, pp. 59-66, 2018.

[23] R. A. Jamil and S. R. ul Hassan, "Influence of celebrity endorsement on consumer purchase intention for existing products: a comparative study," J. Manag. Info, vol. 1, no. 4, pp. $1-8,2018$.

[24] P. C. Kyllonen and H. Kell, "Ability Tests Measure Personality , Personality Tests Measure Ability: Disentangling Construct and Method in Evaluating the Relationship between Personality and Ability," pp. 1-26, 2018.

[25] A. Çelikten and A. Çetin, "Assigning Produc Development Roles to Software Engineers Based on Personality Types and Skills," Acad. J. Sci., pp. 475-486, 2017.

[26] A. Anwar and T. Jalees, "Celebrity Endorsement and Consumer Buying," Mark. Forces - J. Manag. Bus. Econ., vol. XII, no. October 2016, pp. 29-40, 2017.

[27] I. V. C. Silalahi and F. Komalasari, "The effectiveness of celebrity in instagram for fashion local brand of Indonesia customer's attitude towards brand and purchase intention," President University, 2018.

[28] E. S. T. Wang and R. L. Lin, "Perceived quality factors of location-based apps on trust, perceived privacy risk, and continuous usage intention," Behav. Inf. Technol., vol. 36, no. 1, pp. 2-10, 2017

[29] M. Saunders, P. Lewis, and A. Thornhill, Research Methods for Business Students 7th Editio. Edinburgh Gate, Harlow, England: Pearson Education Limited., 2015.

[30] J. F Hair, G.T.M Hult, C.M Ringle, \& M. Sarstedt, A Primeron Partial Least Squares Structural Equation Modeling (PLSSEM)., 2017

[31] K. Khan, A. Rukhsar, and M. Shoaib, "Influence of Celebrity Endorsement on Consumer Purchase Intention," IOSR J. Bus. Manag., vol. 18, no. 1, pp. 6-9, 2016.

[32] T. M. L. Pham and T. V Nguyen, "The Effect of Celebrity Endorsement in Advertising on Consumer Attitude," J. Econ. Dev., pp. 76-86, 2015.

[33] N. Emma and P. Matilde, "Celebrities of Instagram - What Type of Content Influences Followers' Purchase Intentions and Engagement Rate?," Aalto Universit, 2017.

[34] S. K. Kaushal and R. Kumar, "Influence of Attitude towards Advertisement on Purchase Intention: Exploring the Mediating Role of Attitude towards Brand Using SEM Approach," IUP J. Mark. Manag., vol. Vol. XV, N, pp. 44-59, 2016. [Online]. Available: https://www.questia.com/read/1P34296406151/influence-of-attitude-towards-advertisement-onpurchase 